\title{
Effect of Microwave and Enzymatic Treatment on the Recovery of Protein from Indian Defatted Rice Bran Meal
}

\author{
Kakali Bandyopadhyay* , Chaitali Chakraborty and Amit Kumar Barman \\ Department of Food Technology, Gurunanak Institute of Technology (157/F Nilgunj Road, Kolkata-700 114, West Bengal, INDIA)
}

\begin{abstract}
Defatted rice bran meal is an important source of protein along with other micronutrients. Rice bran meal has been utilized to produce protein isolates for potential application in various food products. Attempt has been made to increase the protein solubility by physical means like microwave digestion as well as by microwave digestion followed by homogenization. Simple $\mathbf{4 0}$ sec microwave treatment could give the protein recovery of $78.4 \%$ as against $28.9 \%$ after $1 \mathrm{~min}$ of conventional boiling and $40 \mathrm{sec}$ is taken as optimum time for microwave treatment. The protein recovery is further increased by microwave treatment followed by homogenization. Defatted rice bran meal has also been treated with enzyme papain and viscozyme separately to increase the protein solubility. The yield of protein isolate (RPI), prepared by alkaline extraction followed by acidic precipitation is $10.2 \%$, which is further increased to $14.5 \& 22.4 \%$ by papain, viscozyme modification and $21.1 \& 22.3 \%$ by microwave treatment and microwave treatment followed by homogenization respectively. A maximum of 82.5 and $82.6 \%$ protein has been recovered as soluble protein from de-oiled bran by viscozyme treatment and by $\mathbf{4 0}$ sec microwave treatment followed by 10 min of homogenization. So, microwave treatment along with homogenization is a suitable alternative processes in extracting protein from rice bran meal.
\end{abstract}

Key words: rice bran meal, papain, viscozyme, protein isolate

\section{INTRODUCTION}

Rice bran with $12-20 \%$ protein content may be a potential source of inexpensive high quality protein for new food uses $^{1)}$. The potential food uses of defatted clean bran have been reviewed by Houston ${ }^{2)}$. Rice bran protein containing $3-4 \%$ lysine may be an inexpensive high quality protein for food uses $^{3)}$. Protein has been extracted from rice bran for various food and pharmaceutical applications ${ }^{4-8)}$. Anderson et $a l .{ }^{7}$ have extracted defatted, full fat stabilized and full fat un-stabilized rice bran protein by colloid milling and homogenization. It has been observed that full fat stabilized rice bran showed breakdown in size distribution of protein after colloid milling and homogenization. Rice bran protein has been used as hypoallergenic milk replacers in infant formulas ${ }^{4)}$. Other uses include preparation of protein isolates and concentrates from rice bran meal ${ }^{9}$. Relatively pure rice bran protein can be produced by alkaline extraction followed by precipitation of protein by adjusting the $\mathrm{pH}$ to its isoelectric point ${ }^{10)}$. But the procedure for extracting protein from rice bran must be carefully selected to produce protein isolates or concentrates with desirable functional properties ${ }^{5)}$. Due to strong disulfide bonding and aggregation, a large portion of bran protein cannot be extracted by aqueous extraction ${ }^{5}$. Moreover, alkaline extraction procedures, which are normally used to prepare protein concentrates from rice bran, may change its nutritional characteristics, such as conversion of cystine and serine residues of protein to toxic lysinoalanine ${ }^{5,6}$.

For food purposes rice protein is normally isolated from regular rice flours by enzymatic removal of non-protein components $^{11)}$. Microwave heating is very common in the food industry because of its convenience, rapidity and economy ${ }^{12)}$. It has been found that microwaves cause different biological effects, depending upon field strength, frequencies, waveforms, modulation, duration of exposures, etc. Physical processing with or without enzyme treatments on protein extraction from heat-stabilized defatted rice bran (HDRB) was evaluated ${ }^{13)}$. New value-added product was derived from agricultural by-products : rice bran and soybean meal by means of subcritical water (SW)

\footnotetext{
*Correspondence to: Kakali Bandyopadhyay, Department of Food Technology, Gurunanak Institute of Technology, 157/F Nilgunj Road, Kolkata-700 114, West Bengal, INDIA

E-mail: kakali_gnit@yahoo.co.uk

Accepted May 5, 2012 (recieved for review March 13, 2012)

Journal of Oleo Science ISSN 1345-8957 print / ISSN 1347-3352 online

http://www.jstage.jst.go.jp/browse/jos/ http://mc.manusriptcentral.com/jjocs
} 
hydrolysis, where effect of temperature $\left(200-220^{\circ} \mathrm{C}\right)$, reaction time (10-30 $\mathrm{min})$, raw material-to-water weight ratio $(1: 5$ and $2: 5$ ), was determined on the yields of protein, total amino acids, and reducing sugars in the soluble products $^{14)}$. Although microwave heating is the main cause of these biological effects, no tangible information either on the causes or the mechanisms of microwave has emerged $^{15)}$.

In the present study, protein isolates were produced from defatted rice bran meal available in India by various methods like conventional chemical and enzymatic modification as well as by microwave treatment and microwave treatment followed by homogenization.

\section{MATERIALS AND METHODS}

Materials. Full-fat rice bran was obtained from Sethia Oils Ltd. (Burdwan, W.B., India).

\subsection{Preparation of De-oiled bran}

The de-oiled bran was prepared by solvent extraction in a soxhlet apparatus using hexane (food grade). After complete extraction the meal was desolventized in a vacuum oven at $60^{\circ} \mathrm{C}$ and $4 \mathrm{~mm} \mathrm{Hg}$ for $4 \mathrm{~h}$. The de-oiled meal was stored in desiccator and used for further experiment.

\subsection{Sieving of rice bran meal}

Rice bran meal was screened to pass through an 80 mesh (1770- $\mu$ m openings) sieve. The fraction(through fraction), passing through the screen was used as starting material for further study. Papain (from papaya latex, having activity $100 \mathrm{TU} / 6000 \mathrm{NF}$ ) was purchased from Loba Chemie Pvt. Ltd., Mumbai, India and Viscozyme120 L (an enzyme preparation from Aspergillus with a wide variety of carbohydrase activities bearing $120 \mathrm{FBG} / \mathrm{ml}$ ) was a kind gift from Novo Industry A/S Copenhagen, Denmark were used for enzymatic treatment of rice bran.

\subsection{Preparation of rice bran protein isolate (RPI)}

Deoiled rice bran(through fraction) was mixed thoroughly with 10 times distilled water, $\mathrm{pH}$ of the medium was then adjusted to 10.0 and was stirred for $1 \mathrm{~h}$ at $50-55^{\circ} \mathrm{C}$. The slurry was centrifuged at $4000 \times \mathrm{g}$ for $10 \mathrm{~min}$. The $\mathrm{pH}$ of the supernatant liquid was further adjusted to 4.0 with $1 \mathrm{~N} \mathrm{HCl}$ and again stirred for $1 \mathrm{~h}$ at $50-55^{\circ} \mathrm{C}$, centrifuged at $8000 \times \mathrm{g}$ for $20 \mathrm{~min}$. The solid residue (RPI) thus obtained was collected and dried in a vacuum oven at $50{ }^{\circ} \mathrm{C}$ for $10 \mathrm{~h}$.

\subsection{Preparation of rice bran protein isolate by microwave treatment}

A domestic microwave oven (LG Electronics India Limited, Model MS 257PL, Korea) was used. The experimental setup during microwave heating is shown in Fig 1.

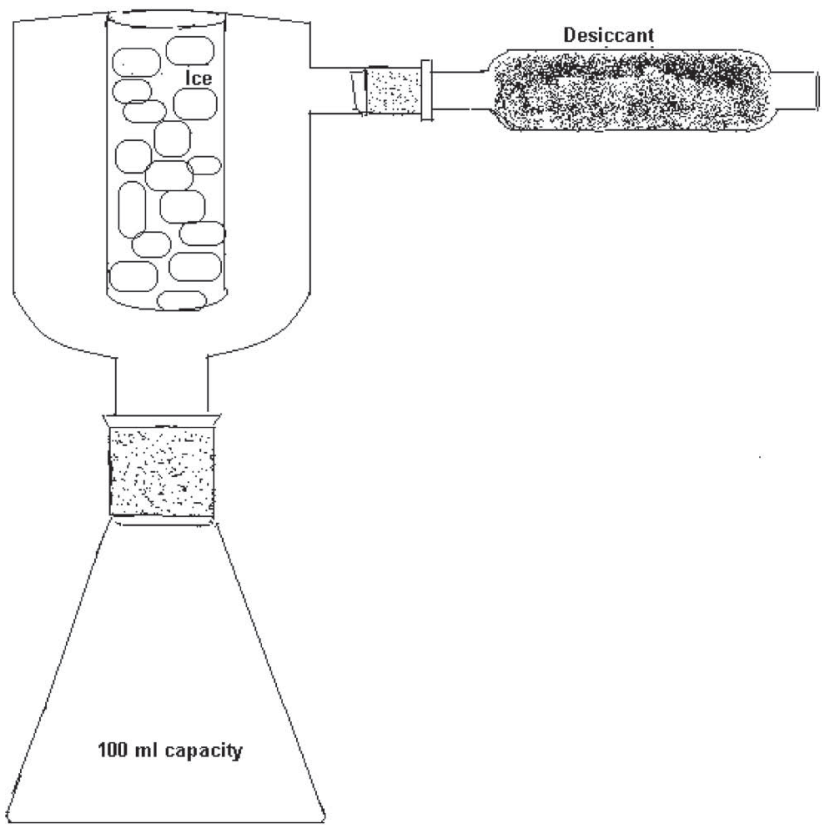

Fig. 1 Experimental setup during microwave treatment.

The slurry containing deoiled bran, after alkaline extraction was adjusted to $\mathrm{pH} 8.0$ and treated in microwave oven for separate time intervals of 20,30,40,60, and $90 \mathrm{sec}$. All samples of $100 \mathrm{ml}$ volume were simultaneously exposed at a frequency of $2450 \mathrm{MHz}$ and operated at $800 \mathrm{Watt}$.

\subsection{Homogenization of microwave treated meal}

After microwave treatment, the slurry was transferred to a homogenizer (REMI Motors, Mumbai, India). The optimum time for homogenization was found to be $10 \mathrm{~min}$. at a speed of $1400 \mathrm{rpm}$. Then each of the slurry was centrifuged at $4000 \times \mathrm{g}$ for $10 \mathrm{~min}$ (Remi Cooling Centrifuge C-24 $\mathrm{BL}$, India). Protein content of both the solid residual meal and supernatant were measured according to Kjeldahl method $^{16)}$ and Lowry et al. method ${ }^{17)}$ respectively. Each supernatant was then lyophilized and freeze-dried (Freeze Dryer FD-5N, Tokyo Rikakikai Co. Ltd., Japan) and stored at $0^{\circ} \mathrm{C}$ for further study.

\subsection{Preparation of rice bran protein isolate by enzymatic modification}

De-oiled rice bran was mixed with water $(10 \% \mathrm{w} / \mathrm{v})$ and $\mathrm{pH}$ of the medium was adjusted to 8.0 and treated separately with $0.1 \%(\mathrm{w} / \mathrm{w})$ papain and $5.0 \%(\mathrm{v} / \mathrm{w})$ viscozyme for $1 \mathrm{~h}$ at $37^{\circ} \mathrm{C}$. After enzymatic treatment the mixtures were heated at $95^{\circ} \mathrm{C}$ for 5 min to inactivate the enzymes. The slurry was centrifuged at $4000 \times \mathrm{g}$ for $10 \mathrm{~min}$. Both the supernatant and solid residual meal was collected separately and their protein content were measured. Each supernatant was then lyophilized and freeze-dried (Freeze Drier FD-5N, Tokyo Rikakikai Co. Ltd., Japan) for further use. The protein isolate obtained by papain treatment is RPIp 
and that by viscozyme treatment is $\mathrm{RPI}_{\mathrm{v}}$.

Total nitrogen content was measured according to the Kjeldahl method, which was converted into protein content using a conversion factor of 6.25. Moisture, crude fiber, ash content, nitrogen solubility index (NSI) and protein dispersibility index (PDI) was determined by Official and Tentative Methods of AOCS ${ }^{16)}$. Silica content was determined by converting about $1 \mathrm{~g}$ sample into ash. Then the ash was taken in a platinum crucible and about $10 \mathrm{ml}$ hydrofluoric acid was added and boiled gently in a heater with asbestos gauze. Gradually silica was removed by converting into volatile fluorosilcic acid. After complete volatilization the crucible was strongly heated directly in the heater for $5 \mathrm{~min}$, the crucible was cooled in a desiccator and weighed. The silica content was calculated from the loss of the weight.

\section{RESULTS AND DISCUSSION}

Commercial rice bran in India is contaminated with rice husk during milling. To reduce the fiber, ash and silica, the rice bran meals were screened through 80-mesh sieve. A fraction (over fraction, yield-30\%) rich in fiber, silica and ash was discarded from the meal. The proximate composition of the de-oiled rice bran meal and its two different fractions (through and over fractions) are shown in Table 1. In the through fraction, the protein content increased from 20.8 to $24.1 \%$ and the silica content reduced from 3.1 to $0.4 \%$. Crude fiber and ash content were also decreased from 16.7 to $13.9 \%$ and 14.9 to $11.3 \%$ respectively by sieving the whole bran meal. The quality of protein in terms of NSI and PDI values were also improved significantly in through fraction. This through fraction with improved quality was used as starting material for further study. Rice bran protein isolates were prepared from this through fraction.

Attempt has been made to increase the protein solubility by physical means like microwave digestion and microwave digestion followed by homogenization. The effect of microwave treatment on the recovery of protein from de-oiled rice bran meal is given in Table 2. Simple $40 \mathrm{~s}$ microwave treatment could give the protein recovery of $78.4 \%$ as against $36.1 \%$ after 1 min of conventional boiling. Further microwave treatment has decreased the protein recovery, probably due to denaturizing of protein. Therefore, $40 \mathrm{~s}$ is taken as optimum time for microwave treatment. The

Table 1 Characteristics of deoiled rice bran meal and its two different fractions obtained by sieving.

\begin{tabular}{cccc}
\hline Characteristics & Deoiled rice bran & Through fraction & Over fraction \\
\hline Moisture(\%) & $10.3 \pm 0.9$ & $11.0 \pm 0.8$ & $8.6 \pm 0.4$ \\
Protein(\%) & $20.8 \pm 0.8$ & $24.1 \pm 1.0$ & $13.1 \pm 0.8$ \\
Crude fiber(\%) & $16.7 \pm 0.6$ & $13.9 \pm 0.8$ & $23.2 \pm 0.7$ \\
Ash(\%) & $14.9 \pm 0.9$ & $11.3 \pm 0.8$ & $21.8 \pm 0.8$ \\
Silica(\%) & $3.1 \pm 0.3$ & $0.4 \pm 0.1$ & $9.3 \pm 0.6$ \\
NSI & $19.6 \pm 0.9$ & $29.9 \pm 0.7$ & $17.1 \pm 0.7$ \\
PDI & $30.0 \pm 0.8$ & $44.0 \pm 1.0$ & $29.0 \pm 0.8$ \\
\hline
\end{tabular}

Values are mean \pm s.d., $n=3$

Table 2 Percent Recovery of Protein from Deoiled Rice Bran Meal (through fraction) by Microwave Treatment and Microwave Treatment Followed by Homogenization at Different Time Intervals.

\begin{tabular}{ccc}
\hline \multirow{2}{*}{$\begin{array}{c}\text { Time of microwave } \\
\text { treatment }(\mathrm{sec})\end{array}$} & \multicolumn{2}{c}{ \% Recovery of protein } \\
\cline { 2 - 3 } & Microwave treatment & $\begin{array}{c}\text { Microwave treatment } \\
\text { followed by homogenization }\end{array}$ \\
\hline 20 & $67.0 \pm 0.9$ & $79.9 \pm 0.9$ \\
30 & $68.7 \pm 0.9$ & $81.6 \pm 1.1$ \\
40 & $78.4 \pm 1.0$ & $82.6 \pm 1.0$ \\
60 & $75.1 \pm 1.0$ & $80.4 \pm 1.1$ \\
90 & $70.3 \pm 1.0$ & $79.2 \pm 1.0$ \\
\hline
\end{tabular}

Values are mean \pm s.d., $n=3$ 
protein recovery was further increased by microwave treatment followed by homogenization as shown in Table 2. A maximum of $82.6 \%$ protein has been recovered after 40 s microwave treatment followed by $10 \mathrm{~min}$ of homogenization.

Defatted rice bran meal has been treated with enzyme papain and viscozyme separately to increase the protein solubility as well as the yield of protein isolate. Papain is well known for its ability to produce protein hydrolyzates from soybean ${ }^{18)}$. The authors have already been produced protein hydrolyzates from sesame protein isolate and rice bran protein by using papain ${ }^{19,20)}$. The yield of different protein isolates prepared from different treated rice bran meals were shown in Table 3. The yield of protein isolate (RPI), prepared by alkaline extraction followed by acidic precipitation was $10.2 \%$, which was further increased to 14.5 , and $22.4 \%$ by papain and viscozyme modification respectively. Microwave treatment had increased the yield to $21.1 \%$, which was further increased to $22.3 \%$ by microwave treatment followed by homogenization.

Microwave heating is one of the most commonly used methods because of its convenience and economy. The depth of penetration is determined by electrical and physical properties, heating patterns and can vary significantly with chemical composition, product temperature and frequency at which the microwave penetrates. Anderson et $a l^{7)}$ have increased protein extractability in rice bran by colloid milling followed by homogenization. Here, in the present study protein extractability get increased by simple inexpensive microwave treatment.

The analytical characteristics of different rice bran protein isolates prepared from different treated rice bran meals are given in Table 3. Different undesirable components like crude fiber, ash and silica contents were very low in these protein isolates. Due to very high protein content, these fractions can be utilized in various food and pharmaceutical formulations.

The percentages of protein recovery from different treated meals are compared in Table 4. About $82.5 \%$ protein has been recovered as soluble protein from de-
Table 4 Percent Recovery of Protein from Different Treated Deoiled Rice Bran Meal (Through fraction).

\begin{tabular}{lc}
\hline \multicolumn{1}{c}{ Treatment } & \% Recovery of protein \\
\hline Alkaline Extraction & $36.1 \pm 0.9$ \\
Papain modification & $54.0 \pm 1.0$ \\
Viscozyme modification & $82.6 \pm 1.0$ \\
Microwave treatment & $78.4 \pm 0.9$ \\
Microwave treatment & $82.5 \pm 1.0$ \\
followed by homogenization & \\
\hline
\end{tabular}

Values are mean \pm s.d., $\mathrm{n}=3$

oiled bran by viscozyme treatment and also by microwave treatment followed by homogenization. This suggests that microwave treatment used in this study had disrupted the extensive network of disulfide bonding and aggregation in the proteins. Therefore, microwave treatment along with homogenization is a suitable alternative processes in extracting protein from rice bran meal.

\section{CONCLUSION}

The maximum of about $83 \%$ protein can be recovered as soluble protein from de-oiled bran by $40 \mathrm{sec}$ microwave treatment followed by 10 min of homogenization. Therefore, microwave treatment along with homogenization can be used as a suitable alternative processes in extracting protein from rice bran meal.

\section{References}

1) Saunders, R. M. The properties of rice bran as food stuff. Cereal Foods World, 35, 632-636 (1990).

2) Houston, D. F.; St. Paul. M. N. Rice bran and polish. In Rice Chemistry and Technology. AmAssoc. Cereal Chemistry, pp. 272-300(1972).

Table 3 Characterization of Different Rice Bran Protein Isolates Obtained from Different Treated Rice Bran Meal.

\begin{tabular}{|c|c|c|c|c|c|c|}
\hline Treament & Product & Yield (\%) & Protein $(\%)$ & $\begin{array}{c}\text { Crude fiber } \\
(\%)\end{array}$ & Ash (\%) & Silica (\%) \\
\hline a. Alkaline Extraction & RPI & $10.2 \pm 0.2$ & $86.2 \pm 1.1$ & $1.8 \pm 0.2$ & $0.3 \pm 0.1$ & 0.03 \\
\hline b. Papain modification & $\mathrm{RPI}_{\mathrm{p}}$ & $14.5 \pm 0.1$ & $89.8 \pm 1.1$ & $1.8 \pm 0.1$ & $0.2 \pm 0.1$ & 0.02 \\
\hline c. Viscozyme modification & $\mathrm{RPI}_{\mathrm{v}}$ & $22.4 \pm 0.2$ & $88.9 \pm 1.2$ & $1.5 \pm 0.1$ & $0.2 \pm 0.1$ & 0.02 \\
\hline d. Microwave treatment & $\mathrm{RPI}_{\mathrm{m}}$ & $21.1 \pm 0.2$ & $89.7 \pm 1.2$ & $1.4 \pm 0.2$ & $0.2 \pm 0.1$ & 0.01 \\
\hline $\begin{array}{l}\text { e. Microwave treatment } \\
\text { followed by homogenization }\end{array}$ & $\mathrm{RPI}_{\mathrm{mh}}$ & $22.3 \pm 0.2$ & $89.4 \pm 1.2$ & $1.5 \pm 0.1$ & $0.2 \pm 0.1$ & 0.01 \\
\hline
\end{tabular}

Values are mean \pm s.d., $\mathrm{n}=3$ 
3) Shih, F. F.; Champagne E. T.; Daigle K.; Zarins, Z. Rice bran and rice flour. Die Nahrung, 43, 14-18(1999).

4) Landers, P. S.; Hamaker, B. R. Antigenic properties of albumin, globulin, and concentrate fractions from rice bran. Cereal Chem., 71, 409-411(1994).

5) Hamada, J. S. Characterization of protein fractions of rice bran to devise effective methods of protein solubilization. Cereal Chem., 74, 662-668(1997).

6) Ansharullah, J.; Hourigan, A.; Chesterman, C. F. Application of carbohydrases in extracting protein from rice bran. J. Sci. Food Agric., 74, 141-146 (1997).

7) Anderson A. K.; Guraya, H. S. Extractibility of protein in physically processed rice bran. J. Am. Oil Chem. Soc., 78, 969-972 (2001).

8) Hamada, J. S. Characteristics of functional properties of rice bran proteins modified by commercial exoproteases and endoproteases. J. Food Sci., 65, 305-309 (2000).

9) Lew, E. J. L.; Houston, D. F.; Fellers, D. A. Use of proteases to enhance the solubility of rice bran proteins. Cereal Chem., 52, 748-750 (1975).

10) Morita, T.; Kiriyama, S. Mass production method for rice protein isolate and nutritional evaluation. J. Food Sci., 56, 1393-1396 (1993).

11) Chobert, J. M.; Bertrand-Harb, C.; Nicolas M. G. Solubility and emulsifying properties of caseins and whey proteins modified enzymatically by trypsin. J. Agric. Food Chem., 36, 883-892 (1988).

12) Yoshida, H.; Takagi, S. Microwave roasting and positional distribution of fatty acids of phospholipids in soybeans (Glycine max L.). J. American Oil Chemists' Society, 74, 915-921(1997).
13) Tang, S.; Navam, S.; Hettiarachchy; Shellhammer. T. H. Protein extraction from heat-stabilized defatted rice bran. 1. Physical Processing and Enzyme Treatments. J. Agric. Food Chem., 50, 7444-7448(2002).

14) Watchararuji, K.; Goto, M.; Sasaki, S.; Shotipruk, A. Value-added subcritical water hydrolyzate from rice bran and soybean meal. Bioresource Technol., 99, 6207-6213 (2008).

15）Rai, S.; Singh, U. P.; Mishra, G. D.; Singh, S. P.; Samarketu, Additional evidence of stable EMF induced changes in water revealed by fungal spore germination. Electro-and Magnetobiology, 13, 253-259 (1994).

16) Official Methods and Recommended Practices of the American Oil Chemists' Society, $4^{\text {th }}$ ed., A.O.C.S. Champaign, IL, (1991), Methods (a) Cd 8b-90, (b) Ca 5b-71, (c) Cd 18-90, (d) Ba 2b-38, (e) Ba 4d-90, (f) Ba 6-84, (g) Ba 5a-49, (h) Ba 10-65, (i) Ba 11-65, (j) Ja 7-86.

17) Van Soest, P. J.; Wine, R. H. Determination of lignin and cellulose in acid detergent fibre with permanganate. J. Assoc. Anal. Chem., 50, 50-55(1967).

18) Wu, W. U.; Hettiarachchy, N. S.; Qi, M. Hydrophobicity, solubility, and emulsifying properties of soy protein peptides prepared by papain modification and ultrafiltration. J. Am. Oil Chem. Soc., 75, 845-850 (1998).

19) Bandyopadhyay, K.; Ghosh, S. Preparation and characterization of papain modified sesame (Sesamum indicum L.) protein isolates. J. Agric. Food Chem., 50, 6854-6857 (2002).

20) Bandyopadhyay, K.; Ghosh, S. Preparation and characterization of protein hydrolysates from Indian defatted rice bran meal. J. Oleo Sci. 57, 47-52 (2008). 